\title{
Developing Deep Understanding and Literacy while Addressing a Gender-Based Literacy Gap
}

\section{Améliorer la compréhension et la littératie tout en tenant compte des disparités entre les sexes}

Yanqing Sun, Jianwei Zhang and, Marlene Scardamalia

\begin{abstract}
Authors
Yanqing Sun, visiting assistant professor at the Albany Institute for Research in Education. Correspondence regarding this article can be sent to ysun@albany.edu Jianwei Zhang, assistant professor in the School of Education, the State University of New York at Albany.

Marlene Scardamalia, Presidents' Chair of Education and Knowledge Technologies and Director of the Institute for Knowledge Innovation and Technology (IKIT), OISE. University of Toronto
\end{abstract}

\section{Abstract}

Online discourse from a class of 22 students ( 11 boys and 11 girls) was analysed to assess advances in conceptual understanding and literacy. The students worked over a two-year period (Grades 3-4), during which they contributed notes to an online Knowledge Building environment-Knowledge Forum ${ }^{\circledR}$. Contributions revealed that both boys and girls produced a substantial amount of text and graphics, and that their written texts incorporated an increasing proportion of less-frequent, advanced words, including academic vocabulary and domain-specific words from grade levels higher than their own. Brief accounts of classroom discourse indicate how deep understanding and vocabulary growth mutually support each other in online and offline exchanges. The gender differences that were observed show boys doing slightly better than girls, suggesting that Knowledge Building has the potential to help boys overcome weaknesses in literacy.

\section{Résumé}

La conversation en ligne d'une classe de 22 élèves (11 garçons et 11 filles) a été analysée pour évaluer les progrès en matière de compréhension conceptuelle et de littératie. Les élèves travaillaient sur une période de deux ans (troisième et quatrième années) pendant laquelle ils ont contribué par écrit à un environnement en ligne de coélaboration de connaissances - Knowledge Forum. Leurs contributions ont révélé que tant les garçons que les filles ont produit bon nombre de textes et d'illustrations, et que leurs textes comportaient une proportion de plus en plus élevée de mots peu courants et plus complexes, 
incluant du vocabulaire théorique et des mots liés à des domaines dépassant leur niveau d'étude. Des résumés de la discussion en classe indiquent comment une connaissance approfondie et l'enrichissement du vocabulaire se soutiennent mutuellement dans les échanges en ligne et en classe. Les différences observées entre les sexes ont montré que les garçons réussissaient légèrement mieux que les filles, ce qui suggère que la coélaboration de connaissances a le potentiel d'aider les garçons à surmonter leurs faiblesses en matière de littératie.

\section{Introduction}

With the advent of the "Knowledge Age" in which social wealth is based upon the capability to create, advance, integrate, and use knowledge, there is need for a multi-literate society able to generate new knowledge, and education to engage all citizens in the process of knowledge creation. Almost half of Ontario Grade 3 students fail to meet Ministry standards in reading and writing (Ontario Public School Boards' Association, 2004). And worldwide, boys tend to lag behind girls in conventional literacy (Mullis, Martin, Gonzalez, \& Kennedy, 2003; OECD \& UNESCO Institute for Statistics, 2003; Ontario Public School Boards' Association, 2004). How to raise the level of literacy among all students and boys in particular represents an important challenge. The purpose of the present study was to explore whether a Knowledge Building approach (Scardamalia \& Bereiter, 2006) might help with the parallel challenges of deep understanding in core subject areas while helping to develop literacy among both boys and girls and addressing the literacy gap between them.

\section{Developing Student Literacy in a Knowledge Building Environment}

Recent research views literacy as a complex social practice learned through dialogic communication and apprenticeship into literate discourse communities (Applebee, Langer, Nystrand, \& Gamoran, 2003; Barton \& Hamilton, 1998). A number of research initiatives explored how to use new technologies-computer-mediated communication in particular-to engage students in authentic literacy communities. For example, Lamy and Goodfellow (1999) created the "Lexica On-line" environment to promote reflective conversation around language topics and language learning issues, with a special focus on vocabulary learning. Students were required to download and read text from the Web, extract and process vocabulary items, and participate in online discussion. Zhao, Englert, Chen, Jones and Ferdig (2000) developed the TELE-Web (Technology Enhanced Literacy Environment on the Web) system that included four elements: Writing Room, Reading Room, Library, and Publishing Room, integrating multi-mode literacy instruction (e.g., oral, listening, reading, and writing). TELE-Web was designed to engage students in inquiry-driven knowledge construction, which necessitates active manipulation of information from multiple sources, generation of text, and interactions and discourse involving peers, teachers, and experts. This work is further advanced through the design of a multi-user, game-based virtual environment that supports authentic language learning and use (Zhao \& Lai, 2008). Clarke and Heaney (2003) documented an "Author

Developing Deep Understanding and Literacy while Addressing a Gender-Based Literacy Gap 
on-Line" (AOL) project, in which pupils read novels related to a topic, wrote reviews and critiques, and interacted with peers, the teacher, book authors, and experts through asynchronous computer conferencing. According to a review by Warschauer (2007), learning environments based on synchronous and asynchronous online communication, when properly used, can promote student-directed interaction, extensive authentic writing with a genuine audience, and collaborative reading.

Many of the studies on literacy learning in online environments imply a connection between language learning and inquiry in content areas, which may benefit both literacy development and disciplinary inquiry (Guthrie, 2004). However, with rare exceptions (e.g., Thakkar, Bruce, Hogan, \& Williamson, 2001), the above-reviewed online environments focus almost exclusively on literacy practices in language classes and programs. The present study investigates student literacy practice as an important aspect of communal Knowledge Building across content areas, exploring the possibility of developing literacy as an important tool and by-product of productive knowledge work (Scardamalia, 2003).

According to Scardamalia and Bereiter (2006), Knowledge Building refers to a process by which members collectively generate and improve ideas of value to their community. Members engage in transformative, Knowledge Building discourse to continually improve their ideas, supported by a computer-based Knowledge Building environment-Knowledge Forum ${ }^{\circledR}$ (see Scardamalia, 2004, for detailed descriptions). Knowledge Forum is a multimedia knowledge database with a set of features supporting collective Knowledge Building. By authoring notes ${ }^{1}$, students contribute ideas, questions, empirical data, reference material, personal experiences/stories and so forth, to views, which are workspaces for various clusters of inquiry. Both notes and views can include multimedia elements (e.g., text, graphics, video). Supportive features for Knowledge Building discourse allow users to co-author notes, build on and annotate notes of community members, create reference links with citations to each other's notes, add keywords, and create rise-above notes to summarize, distil, and advance their discussions. Notes are contributed to views-graphical workspaces-where connections (e.g., building on, rising above, referencing) between notes are evident, and notes can be moved so that they are placed appropriately in light of the graphics background or other organizational schemes created by users. Knowledge Forum also has "scaffolds" to aid the creation of various epistemic artefacts. The theory building scaffold, for example, encourages students to generate ideas corresponding to high level knowledge processes: "My theory," "I need to understand," "New information," "This theory cannot explain," "A better theory," and "Putting our knowledge together." Teachers and students can customize the scaffold supports according to their curricular and learning needs. Activity (e.g., reading, writing, building on, referencing) is recorded automatically. Analytic tools

\footnotetext{
${ }^{1}$ The italicized words in this section represent basic features of Knowledge Forum referred to throughout this article.
}

Developing Deep Understanding and Literacy while Addressing a Gender-Based Literacy Gap 
work as background operations so that patterns of contribution, revision, and interaction for each individual and for the class as a whole can be quickly assessed and fed back into the ongoing process. Within the Knowledge Building context, students generate problems of understanding, share new resources through cooperative reading, and create/improve diverse ideas through face-to-face Knowledge Building discourse. They contribute their problems of understanding, ideas, data, and resources, generated through face-to-face discourse, reading, experiments, and so forth to Knowledge Forum, which supports a process of continual idea improvement.

Knowledge Building in both online and offline environments creates diverse demands and opportunities for high-level literacy practices, including wide, deep, and cooperative reading (Scardamalia, Bereiter, Hewitt, \& Webb, 1996; Zhang \& Sun, in press); extensive and authentic writing that integrates multimedia elements and involves real and responsive audiences (Warschauer, 2007); and open, extended, and continuous dialogic interactions focusing on authentic problems and deep understanding (Applebee, 1996; Bakhtin, 1981; Cummins \& Sayers, 1995; Nystrand, 1997; Swain, 2000; Zhao et al., 2000). It is thus reasonable to expect that Knowledge Building practice should facilitate literacy development, including textual, graphical, and dialogic literacy. Dialogic literacy refers to the ability to engage productively in Knowledge Building discourse whose purpose is to generate new knowledge and understanding (Bereiter \& Scardamalia, 2005). In the Knowledge Building process, idea advancement is the focus of the community; literacy development is an important by-product (Scardamalia, 2003). This perspective has been supported by analyses of contributions to community advances, with corresponding advances in indicators of individual progress such as growth in vocabulary (Sun, Zhang, \& Scardamalia, 2010), reading (Zhang \& Sun, in press), and graphical literacy (Gan, Scardamalia, Hong, \& Zhang, present issue).

\section{Addressing the Gender Gap in Literacy}

Significant gender differences have been observed in performance in and attitude towards language learning, revealing boys' comparative disadvantage in every aspect of the language curriculum (Gorman, White, Brooks, Maclure, \& Kispal, 1988; Millard, 1997;

Ofsted, 1993). An international study evaluated the reading achievement of fourth-grade students from 35 countries including Canada. In all countries, boys had significantly lower achievement than girls (Mullis et al., 2003).

Boys' disadvantage in literacy may be attributed to a number of biological, psychological, social, and pedagogical reasons (Millard, 1997). In term of pedagogical design, current literacy curriculum is heavily dependent on reading and writing of fiction on themes related to human relationships and feelings, which may not be as central to the interests of boys as to girls. Literacy learning and assessment tend to exclusively focus on language classes, with literacy experiences in other subject areas and out-of-school contexts largely ignored. Online and multimedia literacy activities, which are becoming increasingly essential in the real world and in the lives of young children, are Developing Deep Understanding and Literacy while Addressing a Gender-Based Literacy Gap 
under-represented in the curriculum (Greenhow, Robelia, \& Hughes, 2009). As the literature suggests, boys seem to find less purpose and relevance in schoolwork and show a general lack of interest in print-based reading and writing activities. On the other hand, they have strong interests in electronic and graphic forms of literate practice and have been shown to engage eagerly in literacy in public ways and in real-life contexts (Alloway, Freebody, Gilbert, \& Muspratt, 2002). To help boys catch up in literacy, schools need to adapt their literacy teaching "in ways that are more 'boy friendly,' without losing sight of practices that have enabled girls to succeed" (Millard, 1997, p. 167). For example, the literacy curriculum should place more emphasis on learning from non-fiction text, connect literacy learning with the whole school curriculum to promote knowledge construction with text, and integrate new technologies and media to create live and stimulating contexts for literacy learning.

Knowledge Building pedagogy, as noted above, integrates literacy practice into efforts to advance understanding in subject areas that span the school curriculum, increasing the chances of bridging students' diverse disciplinary interests (e.g., science, engineering, mathematics) with literacy work (see, for example, Moss \& Beatty, present issue). More importantly, Knowledge Building practice is largely driven by students' authentic problems and unfolds as a social and interactive process. Students pursue sustained Knowledge Building discourse as a community in both face-to-face and online environments, with the online multimedia environment supporting multiple modes of representing and communicating ideas (see Gan et al., present issue). Given the above features, Knowledge Building pedagogy and technology should engage boys in a broad range of communication skills in a variety of curricular areas and help both boys and girls expand the scope of their textual encounters and language competence. The present study focuses on vocabulary as an indicator of conceptual and literacy growth in a Knowledge Building class. The research question is: Can boys and girls equally develop their vocabulary by participating in sustained Knowledge Building practice? This question is addressed through secondary analyses of an existing dataset that traces a class of students' discourse in Knowledge Forum over two school years (Sun et al., 2010).

\section{Method}

\section{Participants and Contexts}

Participants were 22 students ( 11 girls and 11 boys) from the Institute of Child Study, a laboratory school affiliated with the University of Toronto. Most of the students were from a middle class background and included eight-to-nine-year olds in Grade 3 and nine-to-ten-year olds in Grade 4. We analysed their online discourse over the two-year period-first in Grade 3 and then in Grade 4. In the two years, the students were taught by two different teachers with equivalent experience with Knowledge Building pedagogy and technology (Knowledge Forum). As a part of the science and social studies curricula, the students investigated worms, plants, as well as geography in Grade 3; and living

Developing Deep Understanding and Literacy while Addressing a Gender-Based Literacy Gap 
things, light, and Medieval Time in Grade 4. In these inquiries, the students collectively generated questions and ideas through classroom-based Knowledge Building talks; searched and shared information from books, the Internet, and other sources; generated experiments to test and advance their theories; participated in Knowledge Forum discussions by contributing notes to views corresponding to the various areas of inquiry; and read and built on existing notes to advance their communal knowledge. Problems, hypotheses, experimental findings, and information resources became the objects of sustained discourse in both online and face-to-face environments. Figure 1 provides an overview of notes students in Grade 3 contributed to a view titled "Plants: Composting" with one note open to show Knowledge Forum note features and the beginning of one student's account of how plants grow.

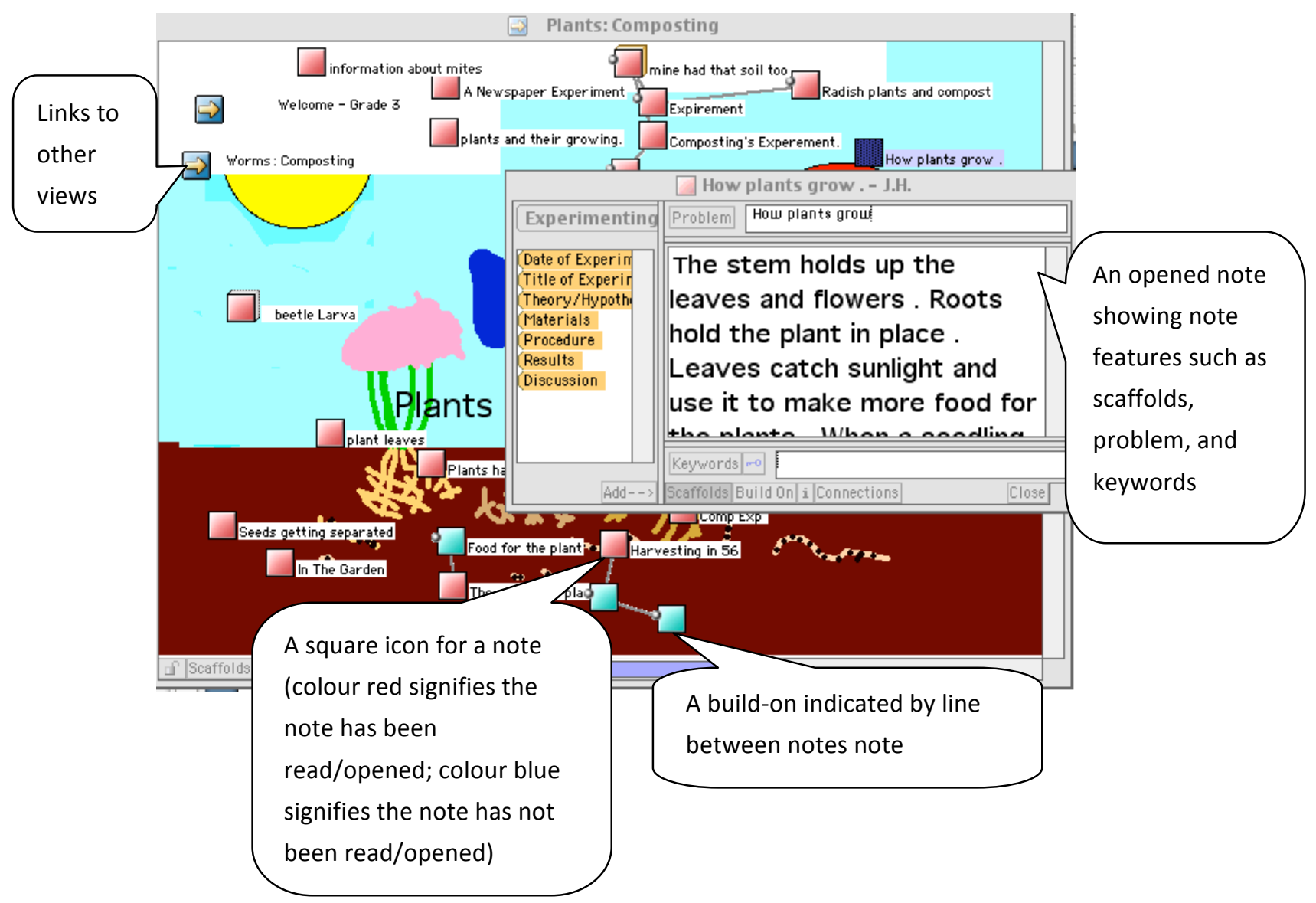

Figure 1: Grade 3 Students' textual and graphical inputs to a Knowledge Forum view titled "Plants: Composting".

The primary data source was the students' online entries in Knowledge Forum over the two-year period, supplemented by the teachers' reflection journals providing accounts for the Knowledge Building designs and specific classroom scenarios, illustrating the

Developing Deep Understanding and Literacy while Addressing a Gender-Based Literacy Gap 
interplay between online and offline processes. We analysed student word use in their Knowledge Forum notes in each half of the school year, which for purposes of convenience we refer to as a "semester" (approximately five months). Specific analyses included:

(a) Total words and distinct words written. We calculated the total words and distinct words written by each student in the two years in Knowledge Forum. Among the distinct words, we identified misspelled words and only counted the number of correctly spelled distinct words.

(b) Grade level of new words. For each of the last three semesters, we used the analytic tools of Knowledge Forum to identify words that were used for the first time by a student (i.e., words that had not been used in previous semesters). Then we classified each new word as within or beyond Grade 4 based on the Basic Spelling Vocabulary List of Graham, Harris and Loynachan (1993). The Basic Spelling Vocabulary List contains 850 high-frequency words that account for about $80 \%$ of the words that elementary students across the United States use in their writing on different themes and genres, with 813 words assigned to the fourth and lower grades. This vocabulary list may not reflect the exact picture of word use among Canadian students; however, it provides a general framework for written words in the vocabularies of students at this age level and has been widely used by researchers and educators from English-speaking countries.

(c) Lexical Frequency Profiles. To assess the growth of students' productive written vocabulary over the two years we used a measure of Lexical Frequency Profiles (Laufer \& Nation, 1995). Use of low-frequency words in spontaneous writing is an indicator of vocabulary richness (Nation, 2001); accordingly, we assessed student "vocabulary in use" by analysing the percentages of word families at various frequency levels in their writing (Laufer \& Nation, 1995). A program called "Range" (Nation, 2001) was used to analyse the Lexical Frequency Profiles for each student's notes in each semester based on three wordlists: first 1,000 word families, second 1,000 word families (West, 1953), and the Academic Word List (Coxhead, 1998). The Academic Word List consists of 570 word families (e.g., assume, establish, conclude, analyse, assess, category) that are not in the most frequent 2,000 word families of English but occur at a reasonably high frequency in academic text across disciplines. These academic words are typical of academic discourse, allowing writers to write in an academic way, referring to others' work, and working with data and ideas.

(d) Use of domain-specific vocabulary. This analysis focused on a sample inquiry on optics conducted in the second semester of Grade 4. Over four months, the students investigated a range of core issues about light through a progressive and emergent process (see Zhang, Scardamalia, Lamon, Messina, \& Reeve, 2007 for details). From the Ontario Curriculum of Science and Technology (Grades 1-8),

Developing Deep Understanding and Literacy while Addressing a Gender-Based Literacy Gap 
two coders cooperatively identified 89 domain words related to light, including names of core concepts, optical devices and optical phenomena. Most of these words come from: (a) Matter and Materials: Materials that transmit, reflect, or absorb light (Grade 4); (b) Energy and Control: Light energy (Grade 4); and (c) Energy and Control: Optics (Grade 8). A few words were identified from Earth and Space Systems for Grade 1 (e.g., heat, light, sun, shadow, etc.) and Grade 6 (e.g., stars, solar, lunar, eclipse). We created a wordlist composed of these 89 words as well as their grammatical variations (e.g., absorbs, absorbed, absorbing for $a b s o r b$ ), with a total of 180 words. Using the analytic tools of Knowledge Forum, we traced the occurrences of these words in the optical discourse.

\section{Results}

\section{Student Writing Over the Two-Year Period}

The students' online discourse included a variety of genres of writing. They posed inquiry questions, proposed and developed theories, reported observations and results from experiments, narrated personal experiences, and justified their ideas. They also introduced new information from authoritative sources, commented on each other's notes to improve ideas, and reviewed and summarized their discussions to achieve a higher level of conceptualisation (see Zhang et al., 2007 for detailed analyses). Over the two years, the students wrote an average of 61.90 notes consisting of 3,867.55 tokens (total words) and 715.45 types (unique words, excluding misspellings), and read $46.50 \%$ (equivalent to a number of 566.84) of the notes of the community. As Table 1 shows, boys wrote a significantly larger number of correct distinct words than girls, with no significant difference in the number of total words.

Table 1: Total Words and Distinct Words Written over Two Years.

\begin{tabular}{ccccc}
\hline & $\begin{array}{c}\text { Boys } \\
\text { Mean (SD) }\end{array}$ & $\begin{array}{c}\text { Girls } \\
\text { Mean (SD) }\end{array}$ & t (df) & p \\
\hline $\begin{array}{c}\text { Total words } \\
\begin{array}{c}\text { Correct } \\
\text { distinct words }\end{array}\end{array}$ & $8798.18(2281.14)$ & $2663.18(583.24)$ & $1.60(11.3)$ & .14 \\
\hline
\end{tabular}

Note. $* \mathrm{p}<.05$

There is report in the literature of unequal engagement of boys and girls in different subject areas, with boys more deeply involved in natural science (Zohar \& Sela, 2003). To determine if Knowledge Building, with emphasis on student-generated theories and authentic problems might engage boys as well as girls in both natural and social science inquiry, we analysed Grade 4 student writing in three Knowledge Building initiatives: (a) Light, an important area in physics-hard science; (b) Living things (e.g., characteristics, Developing Deep Understanding and Literacy while Addressing a Gender-Based Literacy Gap 
biomes, symbiosis, evolution, and photosynthesis) - natural science; and (c) Medieval Times-history and social studies. Figure 2 shows the total words written by the boys and girls in the online discourse. A mixed model ANOVA indicates that the students wrote more words in the light inquiry than in the other two inquiries $(F(2,19)=30.23, p$ $<.001)$. There is no significant gender difference related to any area of inquiry ( $p .10)$, although there is a trend showing that boys wrote more in the inquiry of light while girls wrote more in the inquiry of living things.

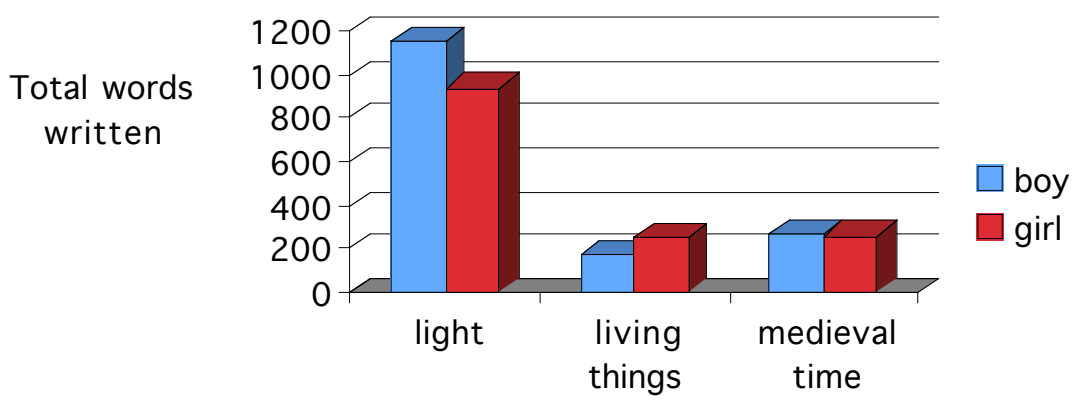

Figure 2: Total words written by boys and girls in three Knowledge Building initiatives. Grade-Level Correspondences for New, Distinct Words

As Table 2 shows, both boys and girls introduced a growing number of new distinct words in each semester, a large proportion of which were beyond a Grade 4 level according to the Basic Spelling Vocabulary List for Grade 1-5 (Graham et al., 1993). Boys included more new words than girls in the last two semesters approaching significance $(p<.10)$ and incorporated more upper grade words in the last semester $(p=.05)$. 
Table 2: The Number of New Distinct Words and New Words Beyond the Grade 4 Level.

\begin{tabular}{ccccc}
\hline & $\begin{array}{c}\text { Boys } \\
\text { Mean (SD) }\end{array}$ & $\begin{array}{c}\text { Girls } \\
\text { Mean (SD) }\end{array}$ & $\mathbf{t}(\mathbf{d f})$ & $\mathbf{p}$ \\
\hline $\begin{array}{c}\text { \# of new words } \\
2^{\text {nd }} \text { semester }\end{array}$ & $113.73(54.32)$ & $98.18(39.76)$ & $.77(20)$ & .45 \\
$3^{\text {rd }}$ semester & $281.00(84.77)$ & $224.09(63.67)$ & $1.78(20)$ & .09 \\
$4^{\text {th }}$ semester & $377.36(95.99)$ & $312.55(67.69)$ & $1.83(20)$ & .08 \\
\hline & \# of new words beyond Grade 4 & & \\
\hline $2^{\text {nd }}$ semester & $64.55(41.44)$ & $49.91(20.65)$ & $1.05(20)$ & .31 \\
$3^{\text {rd }}$ semester & $188.18(70.74)$ & $150.55(46.71)$ & $1.47(20)$ & .16 \\
$4^{\text {th }}$ semester & $284.91(83.42)$ & $225.45(47.30)$ & $2.06(20)$ & .05 \\
\hline
\end{tabular}

Note. New words were defined as words that were used for the first time and had not appeared in writing of previous semester(s). Words used in the first semester were not included in this analysis.

\section{Lexical Frequency Profiles}

An additional analysis considered Lexical Frequency Profiles of students' notes in each semester by analysing their use of different bands of words (see Figures 3 through 5). Mixed model ANOVAs were used to examine differences in percentages across the four semesters with gender as a between-group factor. Along the four semesters, both boys and girls tended to use a decreasing proportion of the $1^{\text {st }} 1000$ words $(F(3,60)=58.73$, $\mathrm{p}<.001)$, with a lower proportion of the $1^{\text {st }} 1000$ words for boys than girls $(\underline{F}(1,20)=$ $5.68, \mathrm{p}<.05)$. The proportion of $2^{\text {nd }} 1000$ words showed a noticeable interactive effect between semester and gender $(\mathrm{F}(3,60)=2.77, \mathrm{p}=.05)$. Tests of simple main effects indicated that boys used an increasing proportion of the $2^{\text {nd }} 1000$ words along the 4 semesters $(\underline{F}(3,18)=5.50, p<.01)$, with no consistent growth for girls. Both boys and girls incorporated an increasing proportion of academic vocabulary along the four semesters $(F(3,60)=33.08, p<.001)$, with no significant gender difference $(p>.10)$. There was a noticeable increase for every student in the proportion of academic words, including the least active students.

Developing Deep Understanding and Literacy while Addressing a Gender-Based Literacy Gap 


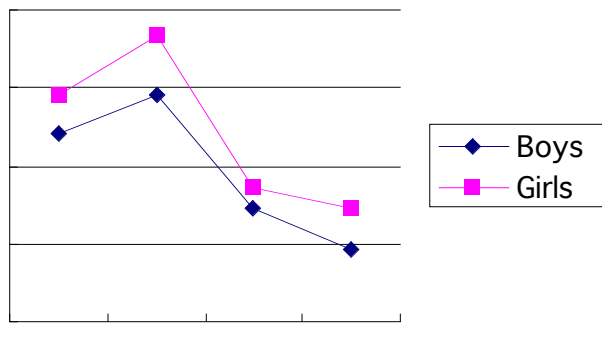

Figure 3: The percentage of first 1000 English words in each student's writing.

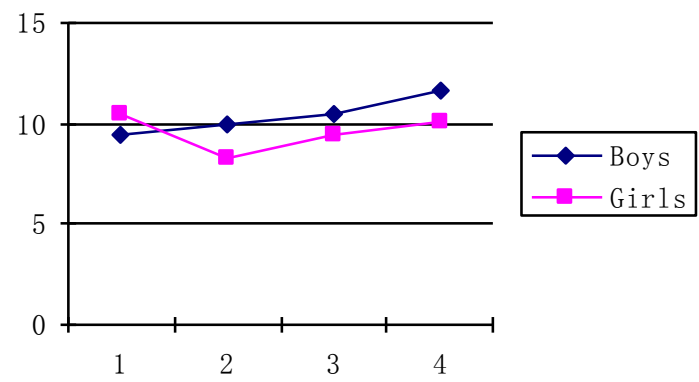

Figure 4: The percentage of second 1000 English words in each student's writing.

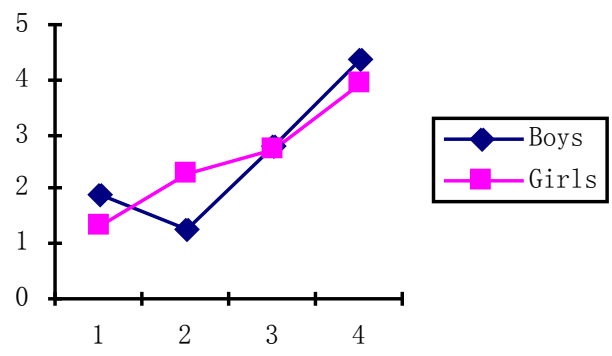

Figure 5: The percentage of academic words in each student's writing.

\section{Use of Domain-Specific Vocabulary}

This analysis was performed based on a Knowledge Building initiative focused on optics in the second semester of Grade 4. Over four months, the students created 287 notes in seven views in Knowledge Forum. Their discourse covered all required topics in the Ontario Curriculum of Science and Technology for Grade 4, as well as topics expected for Grade 8, for instance, light waves, color vision, colors of opaque objects, concave and convex lenses. Pre- post-test results showed significant knowledge advances for individual students. Ratings of students' ideas in the Knowledge Building discourse indicated that they had moved from intuitive understanding of light to scientific accounts (see Zhang et al., 2007).

In the discourse, this community used 120 of the 180 domain-specific words (including grammatical variations) and 71 of the 89 lexemes identified from the curriculum document about optics. The students incorporated almost all the optical vocabulary at or below Grade 4 (41 out of 46 ) and much of the vocabulary expected for upper grades (30 out of 43) into their online discourse. To elaborate on how the students

Developing Deep Understanding and Literacy while Addressing a Gender-Based Literacy Gap 
appropriated new domain-specific vocabulary into their discourse, we further examined a line of their inquiry on how light travels, as reflected in classroom, face-to-face discourse and in Knowledge Forum, aided by the classroom records of the teacher.

The problem of how light ${ }^{2}$ travels caught the students' interests. They first came up with the idea that light travels in a straight line. Later, by talking with an uncle who had a science background, a student, SL, picked up the concept of light wave, which he apparently recognised as something he and his classmates needed to understand. According to the Ontario Curriculum, understanding of "light wave" is expected for students in Grade 8. The apparent contrast between "straight line" and "wave" triggered a debate among the students. In a classroom talk, EL spoke about the wave theory of Christiaan Huygens, as found in a book: Light looks like little "c" emitting from the source. CJL presented his experiment originally conducted by Thomas Young, in which light, passing through a tiny hole in cardboard, produces two light spots on a board held behind the one with the hole. He concluded that the hole separates the wavelengths of light and causes us to see two light spots, thus proving that light travels in waves. After this face-to-face talk, students logged into Knowledge Forum to record their important ideas and problems arising from the talk, as they would normally do for other activities. As an example, Figure 6 shows CIL's note on Thomas Young's experiment. The students continued their discussion online and generated diverse explanations. JD then created a "rise-above" note of these perspectives by saying: "Putting our knowledge together, ... light travels in a straight line but it is a wave. Light is made up of the electromagnetic waves." This then became a new object of discussion, with students continuing to deepen their understanding and expand their vocabulary-mutually reinforcing supports for sustained advancement of community knowledge and personal understanding.

\footnotetext{
${ }^{2}$ Words in italics in this section represent domain-specific words identified from the curriculum document.

Developing Deep Understanding and Literacy while Addressing a Gender-Based Literacy Gap
} 


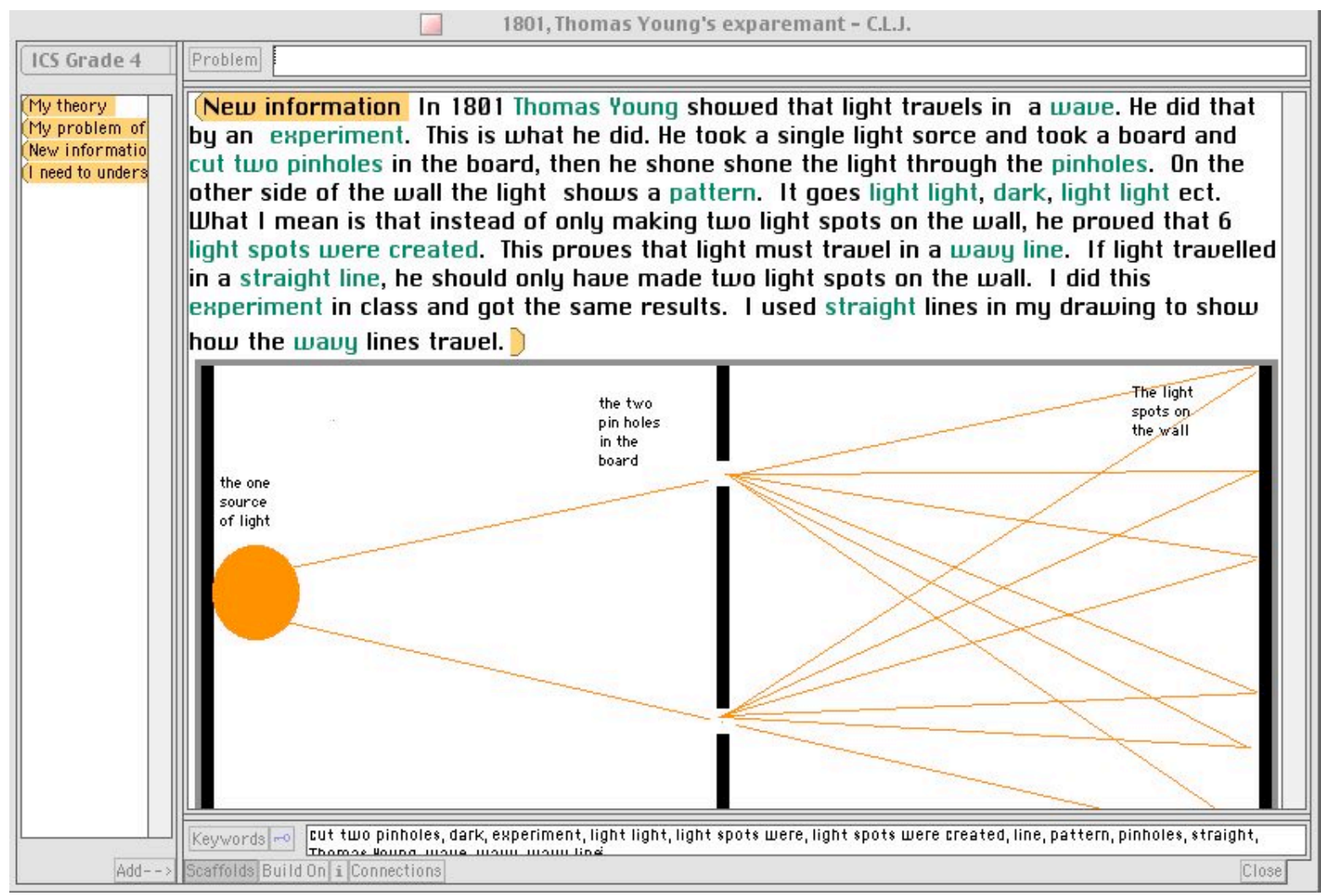

Figure 6: A student note on how light travels.

On average, each student used 43.50 (SD = 8.63) of the 120 words in their writing, using them multiple times for a total of 207.08 times per student $(\underline{S D}=93.42)$. As Table 3 shows, boys used more distinct domain words than girls in their discourse on light ( $p$ $<.05)$, with no significant gender difference in the number of total domain words.

Table 3: Use of Domain-Specific Words in the Knowledge Building Discourse on Light.

\begin{tabular}{ccccc}
\hline & $\begin{array}{c}\text { Boys } \\
\text { Mean (SD) }\end{array}$ & $\begin{array}{c}\text { Girls } \\
\text { Mean (SD) }\end{array}$ & $\mathbf{t}(\mathbf{d f})$ & $\mathbf{p}$ \\
\hline $\begin{array}{c}\text { Distinct } \\
\text { matches }\end{array}$ & $50.82(7.14)$ & $42.44(8.23)$ & $2.52(20)$ & $.02 *$ \\
Total matches & $253.73(123.00)$ & $192.73(33.93)$ & $1.59(11.51)$ & .14 \\
\hline
\end{tabular}

Note. $* \mathrm{p}<.05$

\section{Discussion}

To investigate whether sustained Knowledge Building practice can help both boys and girls elaborate scientific concepts and develop productive written vocabulary, this study

Developing Deep Understanding and Literacy while Addressing a Gender-Based Literacy Gap 
analysed vocabulary used by a group of elementary students in their online Knowledge Building discourse over two school years. We also considered results from related studies on growth in graphical representations (see Gan et al., present issue, for details) and idea advancement (Zhang et al., 2007). There were substantial increases in the amount of written text produced in Knowledge Forum over the four semesters, by both boys and girls. In each semester, they incorporated a large number of new words, $40.65 \%$ of which were beyond a Grade 4 level. The analysis of Lexical Frequency Profiles indicated that students increasingly used less frequent words in their discourse. While the number of distinct words in student writing should not be understood as the actual size of their productive written vocabulary, existing research indicates strong correlations between learners' Lexical Frequency Profiles and their vocabulary size as measured by direct testing. The correlations show that learners who use a lower proportion of the high-frequency words in their text tend to score higher in the vocabulary test (Laufer \& Nation, 1995). The change of Lexical Frequency Profiles in free writing takes a long time (Nation, 2001), as low frequency words need to be brought into productive use. The present study observed changes in the students' Lexical Frequency Profiles, suggesting that with Knowledge Building practice, their' productive written vocabularies increased substantially.

It is particularly noteworthy that both boys and girls had a significant increase in the use of words from the Academic Word List. For example, students widely used words from the following word families: theory, design, create, debate, evidence, hypothesis, approach, challenge, clarify, identify, expand, adjust, link, category, conclude, cooperate, and so forth. Vocabulary choice is a strong indicator of whether the writer has adopted conventions of the relevant discourse community (Nation, 2001). Writers with academic purposes need to gain control of the academic vocabulary in order to be recognised as a member of the academic writing community. The literature suggests that these words are hard to learn and use, and mainly developed late through secondary and higher education (Corson, 1997). The Knowledge Building practice examined in this study created rich opportunities for students to encounter academic vocabulary in the context of authentic knowledge work involving reading, talking, experimenting, and engaging in online discussions. They accordingly brought new vocabulary into productive use in Knowledge Building discourse through the sort of oral and written dialogues that academic communities typically use to advance knowledge in a field (Bereiter \& Scardamalia, 2005). In a separate study a significant correlation was found between student use of academic words in Knowledge Building discourse and the depth of understanding (Sun et al., 2010).

The analysis of the Knowledge Building discourse in the optical inquiry showed that the students addressed many deep issues in the domain, building on their intuitive understanding to achieve more coherent, scientific ideas. Coinciding with the processes for deep understanding, their Knowledge Building discourse incorporated almost all the domain-specific terms expected for Grade 4 or below, as well as about 3/4 of those

Developing Deep Understanding and Literacy while Addressing a Gender-Based Literacy Gap 
expected for upper grades. They collectively identified important concepts from multiple sources (e.g., reading material, dialogues with adults, peer talks, experiments), turned them into objects of sustained inquiry and Knowledge Building discourse in both online and offline environments, and used them as tools to understand deeper issues in the domain. Our earlier analyses revealed a significant correlation between the total occurrences of the domain-specific words in student notes written for the optical inquiry and the complexity level of their understanding summarised in their portfolio notes as rated on a four-point scale from unelaborated facts to elaborated explanations (Sun et al., 2010). Productive engagement in disciplinary Knowledge Building and literacy practices (e.g., learning of new vocabulary, written discourse, reading for problem solving, classroom talk) appear to be supportive of each other and helpful for advancing community knowledge as well as individual achievement.

Both boys and girls were able to develop their vocabulary through Knowledge Building discourse; interestingly, in this study boys outperformed girls according to a number of indicators. As they proceeded with Knowledge Building, boys generated a larger number of distinct words, particularly distinct words beyond a Grade 4 level, words in the second 1000 word families, and technical terms relevant to the domain of inquiry. These results suggest that Knowledge Building practice has the potential to engage boys as well as girls actively and productively in literacy work. It helps to integrate literacy-enhancing activities into authentic inquiry in various content domains. To solve authentic problems and improve ideas in a content domain, students read a wide variety of materials and participate in sustained, Knowledge Building discourse that involves multiple genres of writing, increasing the scope of their textual encounters. The Knowledge Building discourse is supported by the online multimedia environment of Knowledge Forum, which encourages collective advancement of knowledge in a public, communal space. These properties apparently accommodate the preferences of boys as identified by researchers (Alloway et al., 2002; Millard, 1997) and develop their literacy in a more effective way. And fortunately, the context that enriches literate interactions for boys does so for girls as well, seemingly by altering the conditions for their productive engagement and exercise of literacy. Instead of exclusive focus on fiction and text production they engage in graphical, visual and digital literacy as they interact around non-fiction texts across a broad range of social and science topics. They further benefit from engagement in information technology and knowledge innovation, especially helpful for $21^{\text {st }}$ century education.

\section{Conclusions and Implications}

Analyses of students' vocabulary use in Knowledge Building discourses spanning two years suggest that sustained Knowledge Building practice can engage students of both genders in important conceptual work, reflected in their contributions to a multimedia Knowledge Building environment. As results indicate, the environment engages students of both genders in impressive and multiple forms of literacy while eliminating

Developing Deep Understanding and Literacy while Addressing a Gender-Based Literacy Gap 
literacy-based gaps. This suggests that the Knowledge Building approach supported by Knowledge Forum provides an effective multimedia environment to support multiliteracies in diverse contexts and with different groups. In contrast to the reported finding of boys lagging behind girls, both boys and girls-and especially boys-showed advances in productive written vocabulary. This study, along with related studies of students' vocabulary growth (Sun et al., 2010), reading (Zhang \& Sun, in press), and graphical literacy (Gan et al., present issue) in Knowledge Building classrooms, provides evidence that sustained and deep Knowledge Building within and across content areas results in substantial gains in literacy. Advances are reflected in both written and graphic productions, independently assessed and both demonstrating significant idea improvement.

Establishing the finding that deep, sustained work with knowledge and ideas results in substantial gains in literacy has significant implications for school reform initiatives. Literacy development and creative knowledge work, essential for education for a Knowledge Age, can be actualized through the same process. That is because Knowledge Building focuses on sustained idea advancement in a communicative, multimedia environment that is engaging and operates across the school curriculum. Results, which indicate advances in vocabulary following from work in science and social inquiries, indicate that Knowledge Building enables literacy development as an important by-product of sustained work with ideas (Scardamalia, 2003). This finding points to a new, active approach to developing high-level literacy and closing literacy gaps without limiting time or resources committed to sustained and deep work with knowledge. Specific designs for facilitating literacy in Knowledge Building classes (e.g., cooperative reading of difficult text, collective responsibility for language use) were elaborated in two recent papers (Sun et al., 2010; Zhang \& Sun, in press).

The findings of this study were derived from analyses of a relatively small sample of students focusing on naturally generated online discourse data. In a follow-up study both online and classroom-based data were analysed and this analysis provides an in-depth account of student literacy practices in the service of collaborative idea advancement (Zhang $\&$ Sun, in press). Further studies are needed to reproduce these findings using a control group design and a larger sample of students, with multiple measures to assess student vocabulary growth (e.g., pre-post-tests, essay writing), and encompassing other literacy performances such as writing quality.

\section{Acknowledgements}

This research was funded by an Initiative on the New Economy (INE) Grant from the Social Sciences and Humanities Research Council of Canada (512-2002-1016). An earlier draft of this article was presented at the Annual Meeting of American Educational Research Association (Chicago, 2007). We are thankful to Bill Egnatoff and the two anonymous reviewers for their comments and suggestions. We owe special thanks to the students, teachers, and principal of the Institute of Child Study of the University of Developing Deep Understanding and Literacy while Addressing a Gender-Based Literacy Gap 
Toronto, for the insights, accomplishments, and research opportunities enabled by their work.

\section{References}

Alloway, N., Freebody, P., Gilbert, P., \& Muspratt, S. (2002). Boys, literacy and schooling: Expanding the repertoires of practice. Canberra, ACT, Australia: Commonwealth Department of Education, Science and Training.

Applebee, A. N. (1996). Curriculum as conversation: Transforming traditions of teaching and learning. Chicago, IL: University of Chicago Press.

Applebee, A. N., Langer, J.A., Nystrand, M., \& Gamoran A. (2003). Discussion-based approaches to developing understanding. American Educational Research Journal, $40(3), 685-730$.

Bakhtin, M. M. (1981). The dialogic imagination: Four essays (C. Emerson \& M. Holquist, Trans.). Austin, TX: University of Texas Press.

Barton, D., \& Hamilton, M. (1998). Local literacies: reading and writing in one community. London: Routledge.

Bereiter, C. \& Scardamalia, M. (2005). Technology and literacies: From print literacy to dialogic literacy. In N. Bascia, A. Cumming, A. Datnow, K. Leithwood, \& D. Livingstone (Eds.), International handbook of educational policy (pp. 749-761). Dordrecht, Netherlands: Springer.

Clarke, L., \& Heaney, P. (2003). Author on-line: Using asynchronous computer conferencing to support literacy. British Journal of Educational Technology, 34(1), 57-66.

Corson, D. J. (1997). The learning and use of academic English words. Language Learning, 47, 671-718.

Coxhead, A. (1998). An academic word list. Occasional publication Number 18, LALS, Victoria University of Wellington, New Zealand.

Cummins, J., \& Sayers, D. (1995). Brave new schools: Challenging cultural illiteracy through global learning networks. New York, NY: St. Martin's Press.

Gan, Y. C., Scardamalia, M., Hong, H. Y., \& Zhang, J. (2010). Making thinking visible: Growth in graphical literacy, Grades 3 to 4 . Canadian Journal of Learning and Technology, 36(1).

Gorman, T., White, J., Brooks, G., Mclure, M., \& Kispal, A. (1988). Language performance in schools: Review of APU language monitoring 1979-1983. London: HMSO.

Developing Deep Understanding and Literacy while Addressing a Gender-Based Literacy Gap 
Graham, S., Harris, K., \& Loynachan, C. (1993). The basic spelling vocabulary list. Journal of Educational Research, 86, 363-368.

Greenhow, C., Robelia, E., \& Hughes, J. (2009). Web 2.0 and classroom research: What path should we take now? Educational Researcher, 38(4), 246-259.

Guthrie, J. T. (2004). Classroom contexts for engaged reading: An overview. In J. T. Guthrie, A. Wigfield, \& K. C. Perencevich (Eds.), Motivating reading comprehension: Concept-oriented reading instruction (pp. 1-24). Mahwah, NJ: Erlbaum.

Lamy, M. N., \& Goodfellow, R. (1999). "Reflective conversation” in the virtual language classroom. Language Learning \& Technology, 2(2), 43-61.

Laufer, B., \& Nation, P. (1995). Vocabulary size and use: Lexical richness in L2 written production. Applied Linguistics, 16, 307-322.

Millard, E. (1997). Differently literate: Boys, girls and the schooling of literacy. London: Falmer.

Moss, J., \& Beatty, R. (2010). Knowledge Building and mathematics: Shifting the responsibility for knowledge advancement and engagement. Canadian Journal of Learning and Technology, 36(1).

Mullis, I.V.S., Martin, M.O., Gonzalez, E.J., \& Kennedy, A.M. (2003). PIRLS 2001 international report: IEA's study of reading literacy achievement in primary schools. Chestnut Hill, MA: Boston College.

Nation, I. S. P. (2001). Learning vocabulary in another language. Cambridge, UK: Cambridge University Press.

Nystrand, M. (1997). Opening dialogue: Understanding the dynamics of language and learning in the English classroom. New York, NY: Teachers College Press.

OECD (Organisation for Economic Co-operation and Development) \& UNESCO Institute for Statistics (2003). Knowledge and skills for life: First results from PISA 2000. Paris, France: Origanization for Economic Co-operation and Development.

Ofsted (1993). Boys and English. London: HMSO.

Ontario Public School Boards' Association (2004). Boys lag as Ontario grade 3 and 6 students improve scores in standardized tests. Fast Reports, 16(26), 3.

Scardamalia, M. (2003). Crossing the digital divide: Literacy as by-product of Knowledge Building. Journal of Distance Education, 17 (Suppl. 3, Learning Technology Innovation in Canada), 78-81.

Developing Deep Understanding and Literacy while Addressing a Gender-Based Literacy Gap 
Scardamalia, M. (2004). CSILE/Knowledge Forum ${ }^{\circledR}$. In A. Kovalchick, \& K. Dawson (Eds.), Education and technology: An encyclopedia (pp. 183-192). Santa Barbara, CA: ABC-CLIO, Inc.

Scardamalia, M., \& Bereiter, C. (2006). Knowledge Building: Theory, pedagogy, and technology. In K. Sawyer (Ed.), Cambridge Handbook of the Learning Sciences (pp. 97-118). New York: Cambridge University Press.

Scardamalia, M., Bereiter, C., Hewitt, J, \& Webb, J. (1996). Constructive learning from texts in biology. In K.M. Fischer, \& M. Kirby (Eds.), Relations and biology learning: The acquisition and use of knowledge structures in biology (pp. 44-64). Berlin: Springer-Verlag.

Sun, Y., Zhang, J., \& Scardamalia, M. (2010). Knowledge Building and vocabulary growth over two years, Grades 3 and 4. Instructional Science, 38 (2), 247-271.

Swain, M. (2000). The output hypothesis and beyond: mediating acquisition through collaborative dialogue. In J. Lantolf (Ed.), Sociocultural theory and second language learning (pp. 97-114). Oxford, UK: Oxford University Press.

Thakkar, U., Bruce, B.C., Hogan, M.P., \& Williamson, J. (2001). Extending literacy through participation in new technologies. Journal of Adolescent \& Adult Literacy, 45(3), 212-219.

Warschauer, M. (2007). Technology and writing. In J. Cummins and C. Dvison \& (Eds.), International Handbook of English Language Teaching (pp. 907-918). New York, NY: Springer.

West, M. (1953). A general service list of English words. London, UK: Longman, Green \& Co.

Zhang, J., Scardamalia, M., Lamon, M., Messina, R., \& Reeve, R. (2007). Socio-cognitive dynamics of Knowledge Building in the work of nine- and ten-year-olds. Educational Technology Research and Development, 55(2), 117-145.

Zhang, J., \& Sun, Y. (in press). Reading for idea advancement in a grade 4 Knowledge Building community. Instructional Science.

Zhao, Y., Englert, C.S., Chen, J., Jones, S.C., \& Ferdig, R.E. (2000). The development of a Web-based literacy learning environment: A dialogue between innovation and established practices. Journal of Research on Computing in Education, 32(4), 435-454.

Zhao, Y., \& Lai, C. (2008). Massively Multi-Player Online Role Playing Games (MMORPGS) and foreign language education. In R. Ferdig (Ed.), Handbook of Research on Effective Electronic Gaming in Education (pp. 402-421). New York: IDEA Group.

Developing Deep Understanding and Literacy while Addressing a Gender-Based Literacy Gap 
Zohar, A., \& Sela, D. (2003). Her physics, his physics: Gender issues in Israeli advanced placement physics classes. International Journal of Science Education, 25(2), 245-268.

Developing Deep Understanding and Literacy while Addressing a Gender-Based Literacy Gap 